\title{
A Concise History of Indian Sacred Art: Some Philosophical Considerations
}

\author{
Paulo Nuno Martins* \\ Interuniversity Center for History of Science and Technology, New University of Lisbon, Campus of Caparica, \\ Building VII, Floor 2, 2829-516 Caparica, Portugal
}

*Corresponding Author: Paulo Nuno Martins, Interuniversity Center for History of Science and Technology, New University of Lisbon, Campus of Caparica, Building VII, Floor 2, 2829-516 Caparica, Portugal

\begin{abstract}
In this essay, I intend to describe in a concise way the History of Indian Sacred Art through ages (Dravidian and Aryan period, Buddhist period, Muslim and Mughal and Rajput period, Western and Contemporary period) in order to study the main reason that leads the Eastern culture, in particular, Buddhists and Hindus to go to their Sacred Temples to experience Darshan (from Sanscrit "see God"). In this regard, I will make some philosophical considerations, emphasizing that this is also the motive that leads Western culture, namely, Christians, Muslims and Jews to go to their Temples.
\end{abstract}

Keywords: History of Indian Art, Indian Sacred Temples, Darshan, philosophy of science.

\section{INTRODUCTION}

Generally speaking, Indian art has a strong religious characteristic with various influences over time. Up to $12^{\text {th }}$ century is evident the Hindu, Buddhist and Jain influence in Indian Sacred Art which was expressed through sculptures and images of the deity placed in several Shrines. From $12^{\text {th }}$ to $17^{\text {th }}$ century, with the Muslim invasions and Mughal dinasty, the Islamic art began to have a strong influence into Indian Sacred art. For example, the Islamic art has no Sacred images in their Temples. Moreover, while Hindu and Buddhist advocates the cremation of the dead, on the contrary, such a practice is not advocated by Islam. In this regard, many of their dead (mainly Sultans and Mughal kings) were buried themselves within the Sacred Temples [1].From $17^{\text {th }}$ to the $19^{\text {th }}$ century, through contact with European civilizations, such as Portuguese and British (among others), the Indian Sacred art also undergone through deep changes in their style because the architecture of the Christian Temples, the Sacred images and the rituals are quite different from the Eastern culture and religion[2]. On the other hand, another purpose of this article is to make some philosophical considerations about the motivations that lead the Hindus to visit Indian Temples and Indian Sacred Art. Some studies [3] have suggested that one of the reasons is to be able to "see" the image of the god or goddess who inspires them and bring them to know their true essence: the Soul- which is described in some Sacred Indian Books [4]. This is the core of the Darshan experience (from Sanskrit "see God"). In this regard, Quantum Mechanics claims the interconnection between the consciousness mind of the observer and the Sacred entity observed [5], while the Brain sciences hold that extrasensory perception (such as "clairvoyance" of the deity) covers several areas of the brain still unknown in medical science [6].

\section{METHODS}

In this concise article on the History of Indian Sacred Art, I collected and analyzed the main articles and books, in this area of research, that are available in libraries. Thus, I selected the 30 most important items, based on the "impact factor" of the article and the "reference" books on this issue with the purpose of being useful to the reader who wants to have a precise and rigorous idea on this subject, but without being too detailed.

\section{RESULTS AND DISCUSSION}

In this section, I will present the most relevant results of my research work about the concise History of Indian Sacred Art that will be useful to the philosophical considerations performed in the section 4 . 


\subsection{A Concise History of the Indian Sacred Art: The Dravidian Period Up to the Aryan Invasions (3000 B.C.-700 B.C.)}

In historical terms, around 3000 B.C., the Dravidian people, one of the oldest civilizations that inhabited the Indus Valley, had already several utensils, such as pots and pans, which had drawn the pipal tree (a type of large Indian tree) which become India's sacred tree (the tree of enlightenment of Buddha). There are also some seals with recorded animals, such as cows, elephants that have a religious or mythical connotation in Indian civilization [7]. Furthermore, the Dravidian people had an architecture that already made the planning of their streets and cities for the quality of life of their population, such as Mohenjo-Daro and Harrapa - the origin of the concept of "urbanization" - which was a sign of spiritual development of this civilization[8]. Around 1500 B.C., with the invasions of the Aryan people, which brought the Vedas (the sacred texts of Hinduism), the four classes of Vedic society were formed, which today still exist, namely the priests and religious (brahmins), the rulers and warriors (kshatriyas), the patrons (vaishyas), and finally the artists and the people in general (shudras). Due to the low status of artists, according to the Indian caste system, most of those who built the Hindu Temples and the Indian Sacred Art have become anonymous [9]. In this regard, around 800 B.C., the Aryan people built many Vedic altars, known as "Ishtaka", within their Temples (mostly situated in the Ganges valley), with the purpose of practicing religious rituals advocated in Vedas [10].

\subsection{A Concise History of the Indian Sacred Art: The Buddhist Period Up to the 12th Century (700 B.C.-12th Century)}

Around 250 B.C, the Indian emperor designated by Ashoka, of the Mauryadinasty (273B.C.-232 B.C.), conquered most of India. The most important monument of this time are the several Ashoka Columns, one of them located in Sarnath, place where Buddha made his first Sermon, after the Enlightenment [11]. Another important monument of the Buddhist period is the Great Stupa, in Sanchi [12], which was built around 250 B.C. and renovated and enlarged around 50-25 B.C..This monument describes, through visual images carved on pillars, the Buddha's life, namely, Birth, Great Departure, Enlightenment, first Sermon and Death. This monument is constituted by an hemispherical dome (symbolizing the heaven) enclosed by a railing (symbolizing the mountain) with four gateways (at the cardinal points). Furthermore, around 100-200 B.C., it was built the largest stupa that describes the Buddha's previous life, as king Mandhata, designated by Amaravati Stupa[13]. Nowadays, this monument is reduced to ruins, being the archaeological finds scattered by the Museums of London, Madras and Amaravati. Furthermore, during the Gupta Empire (240 B.C.-590 A.C.), called by the "Golden Age of India", it was created a Buddha's image, known as Gupta Buddha [14], which served to inspire many devotees in Buddhist Cave Monasteries and Cave Temples, such as the Ajanta Caves [15], in Maharashtra. However, with the Muslim invasions in $10^{\text {th }}$ and $12^{\text {th }}$ centuries, Buddhism in India began to disappear and the Ajanta Caves were abandoned.

Meanwhile, the Hindus sought to give prominence to their deity, namely Shiva and Durga. An example of a Temple extolling Shiva is the Elephanta Caves [16], located on Elephanta Island, in the port of Mumbai, that were built around 810 and 1260, and consist of several chambers and shrines that contain reliefs, sculptures and a Temple dedicated to Shiva.It is an example of the Shiva cult. Furthermore, there is the Vimala Temple,located within the Jagannath Temple complex, in Puri, which is the most sacred Temples of the Hindu Goddess, identified with Parvati, Lakshmi and Durga. It is considered to be an example of the importance of the Shakti cult [17].

We have also the Ellora Caves [18], in Maharashtra, which consist of 12 Buddhist caves (built between $5^{\text {th }}$ and $8^{\text {th }}$ century), 17 Hindu caves (built between $8^{\text {th }}$ and $10^{\text {th }}$ century) and 5 Jain caves (built between $11^{\text {th }}$ and $13^{\text {th }}$ century)and are a good example of a syncretism of Hindu, Buddhist and Jain ideas and iconography. The Buddhist caves are Monasteries (viharas) with the form of Stupa and containing statues of Buddha. The Hindu caves contain several sculptures illustrating the avatars of Vishnu, as well as a gigantic cave containing a lingam of Shiva, known as the Kailasa Temple. The Jain caves follow the models of the Hindu Art, illustrating the specific characteristics of the Jain religion.

In relation to the Hindu architecture of this period [19],there are two main types: Nagara in northern India [20] which were built during the Hindu dinasty designated by Chandella (830-1300)and Dravidic in southern India [21]which were built during various Hindu dynasties, such as Pallavas (600-900), 
Rashtrakutas (750-970), Chalukyas (970-1180), Cholas (850-1280), Hoysalas (1100-1340), Vijayanagara (1340-1560).Both of them have some general characteristics [22], such as the Garbhagriha (from Sanscrit "womb chamber") where is the image of the deity (Shiva, Vishnu, Durga, and so on). The Garbhagriha is crowned by a tower called by Shikhara (in the northern India) or Vimana (in the southern India) and Amalaka that supports the Kalasha (pinnacle element of the Temple). The Garbhagriha is next to Mandapa (hall of festival for public rituals, such as the Hindu wedding) and the ArdhaMandapa (the entrance or the hall of offerings). The Dravidian architecture has a particular feature called gopuram[23] (the monumental gatehouse tower at the entrance of a Hindu Temple).

\subsection{A Concise History of the Indian Sacred Art: The Muslim, Mughal and Rajput Period(12th Century-19th Century)}

In relation to the contribution of Islamic Art [24] to the Indian Sacred Art, this lies in the development of their abstraction. For example, in the Islamic art, the iconographic and symbolic representations of Buddha and Hindu gods that are presented in their Temples, they were replaced in Islamic art by geometry and calligraphy in the architecture of the Mosques.

In historical terms, during the Sultanate of Delhi in Northern India, that comprised five dynasties, namely Mamluk (1206-1290), Khali (1290-1320), Tughlak (1320-1414), Sayyid (1414-1451), Lodi (1451-1526), this region was ruled by Muslim Sultans. The Sultan Qutb al-Din Aybak (belonging to the Mamluk dynasty) ordered to build one Temple named by Quwwat al-Islam Mosque, in Delhi. This Mosque has grey colonnades together with a grand line of several arches extending from north to south with Arabic calligraphy related with themes of the Koran, but with no Sacred images. Furthermore, this Mosque has a QutubMinar used for prayer and a tomb named by Iltumish (belonging to the Khali dynasty) located inside the walls of this Muslim Temple.

In the southwest of the Mosque, there is a Madrasa (any type of educational institution for the study of Islamic religion) which was ordered to be built by Sultan Ala al-Din Khalji (belonging to the Khali dynasty). Moreover, Firuz Shah Tughlak (belonging to the Tughlakdinasty) replaced the top of the QutubMinar by two floors with red sandstone and marble when this minaret was struck by a lightning bolt. In 1398, Timur or Tamerlane (belonging to the Sayyid dinasty) defeated the Sultan of the Tughlakdinasty and went on to rule the Delhi Sultanate. In 1451, it happened the emergence of the Lodiswho built several tombs throughout the city of New Delhi, namely the octonal tomb of Muhammad Shah Lodi (belonging to the Lodi dinasty), in Delhi.

Meanwhile, Hindu monarchs established the kingdom of Vijayanagara (from Sanscrit "City of Victory") in southern India which means that two different strands of Sacred art emerged in India, between the $14^{\text {th }}$ and the $16^{\text {th }}$ century: the Islamic Sacred art in northern India and the Hindu Sacred Art in southern India. One of the most important monuments of the Vijayanagara empire[25] is the Lotus Mahal because is a combination of Dravidic with Islamic architecture: the arches and domes are Islamic, while the tower and the halls decoration are Dravidic style. This city is composed by the Royal Enclave (close to the Lotus Mahal), known as Hazara Rama, and the Sacred Centre. The Royal Enclave is used to celebrate the Mahanavami festival, while the Sacred Centre consists of four major Temples. However, in $16^{\text {th }}$ and $17^{\text {th }}$ century, the Muslims established a Sultanate in southern India, named by Deccani(1527-1686), that comprised five kingdoms, namely,Bijavur, Ahmadnagar, Bidar, Berar and Golgonda that reunited to conquer the Vijayanagara empire.

On the other hand, in 1526, the Delhi Sultanate ended when Babur, founder of the Mughal dynasty, defeated the last Lodi king. Moreover, in 1686, the Deccani sultanates also succumbed to the Mughal emperors. In relation to the influence of the Mughal art to the Indian Sacred art, we have the emblematic monument named by Taj-Mahal, in Agra [26]which was commissioned to build by Shah Jahan, from 1632 to 1653, for his beloved Aryumand Banu Begam, better known as Mumtaz Mahal. Taj-Mahal means " The Jewel of the Palace " and is related with the wife and consort of Shah Jahan. In fact, this Islamic monument has become a symbol of Love, intending the Emperor to perpetuate it through a monument that contains a mausoleum with his beloved rests.

In architectural terms, this monument consists of a main entrance in red stone (called "darwaza") that gives access to the famous central monument constituted by white marble, inlaid with semiprecious stones and with verses from the Koran, having a dome with threads of gold. This monument has also 
two Mosques (one mosque and one "jawab") and four minarets. This architectural complex is surrounded by gardens or ChagarBagh (from Persian "Garden of the Paradise") intending to represent symbolically the spiritual joy that is described in the Koran (as in the Bible) and that one wants to see manifested on Earth. In fact, in these gardens, there are four streams of water flow (from four cardinal points) coming from the Yamuna river, so as to symbolize Life in the "Garden of Paradise" described in the Koran.

On the other hand, during the Muslim dinasty (the Delhi Sultanate) and Mughal dinasty several Hindu Rajput kingdoms [27] were established, such as, Jaipur, Chittor, Mewar (Udaipur) and many others (in the Rajasthan state). The various Rajput kingdoms had different degrees of collaboration and opposition to the Muslim and Mughal governments. The most important kingdom of Rajput was that of Mewar. Mewar's main artistic work is the City Palace, in Udaipur that was built in 1559, on the slope of a hill (Rana's hill), near Pichola lake. It is formed by several palaces in granite and marble that are within an architectural complex characterized by a combination Rajasthani and Mughal art. This monument was enlarged by successive generations of Maharanas (the Mewar rulers).

\subsection{A Concise History of the Indian Sacred Art: The Western and Contemporary Period}

The Indian Sacred art came into contact with the Western Sacred art, in the $16^{\text {th }}$ and $17^{\text {th }}$ century, through the work of Portuguese artists, such as the Church of Bom Jesus, in Goa[28] which has the image of the Christian Saint Francis Xavier. This Temple was built in laterite and marble, inlaid with precious stones. Inside the church are several paintings about the life of St. Francis Xavier. There is also a tomb with the mortal remains of St. Francis Xavier. Furthermore, this Christian Temple has several objects used in Catholic rituals, such as chalices for Holy communion and pilgrimage padiola for processions. Also, in the 16th century, the Portuguese artists also built the Church of St. Francis of Assisi, which has a chapel with three altars and externally by a humble building containing and an outer bell. Later, this Christian Temple was enlarged and restored, having been built a central nave and a tabernacle where is possible to worship the Christian Holy Sacrament. Nowadays, this Christian Temple houses the Archaeological Museum.

Meanwhile, the British people also arrived in India. The British artists were responsible for the construction of the Christians Church of St. John, in Calcutta and Church of St. Andrew, in Madras [29]. The Church of St. John was built in the $18^{\text {th }}$ century and is a combination of brick and stone with its interior constituted by gray-blue marble. The Church of St. Andrew was built in the $19^{\text {th }}$ century and is constituted by a circle with rectangular compartments which are crowned by a shallow dome.

Furthermore, there was an artistic exchange between Portuguese and British Sacred art, in India, such as in the Church of St. Thomas, in Madras. This Christian Temple was built as a Church by Portuguese, in the $16^{\text {th }}$ century, and rebuilt as a Cathedral by the British, in $19^{\text {th }}$ century. This Cathedral has a tomb with the mortal remains of St. Thomas. Nowadays, the St. Thomas Cathedral (Minor Basilica) is a pilgrimage center for Christians in India, where the Virgin Mary is dressed with a sari, while Christ stands on a lotus.

In the $20^{\text {th }}$ century, after the India's independence from the European settlers, Indian artists have sought to incorporate many of the new technological techniques of Western culture into their artistic work, but maintaining the roots of the Indian Sacred art. For example, the painting designated by Bharat Mata (from Sanscrit "Mother India") [30] whose author is Abanindranath Tagore of the Bengal school, it shows a beautiful woman with four arms (similar to the Hindu goddess, Durga), but with an halo around her head (similar to the Christian goddess, Virgin Mary). Furthermore, in the $19^{\text {th }}$ century the Ajanta Caves were rediscovered and there have been various efforts for the restoration and conservation of these caves through specific techniques for this purpose.

\section{Conclusions}

In Indian culture, its history is intertwined with religion, being this an essential characteristic of this people [31]. This is the reason why I'm going to make some philosophical considerations on the relationship of the History of Indian Sacred Art and the concept of Darshan.

First, the Indian Temples[32] are a synthesis of art and philosophy because they are a place for pilgrimage that supports the four principles of all sustainable human life: the Artha (professional progression, wealth), Kama (desire, happy marriage), Dharma (harmony, ethical practice) and Moksha (self-knowledge, spiritual enlightenment). Nevertheless, most of the artists, who built the Indian 
Temples and performed the Indian Sacred art, remained anonymous due to the caste system of Indian society: priests, rulers and warriors, patrons, artists and the people in general. In fact, this society defends the Indian philosophical conviction that human beings need to be born repeatedly designated by "Reincarnation" [33] -to attain the purity of heart that enables them to "see the Divine" or Darshan. Thus, the construction of the Hindu Temples or perform Indian Sacred Art has been one of the ways to achieve this goal quickly, balancing the effects of personal actions or "karma" (from Sanscrit "action"). However, Darshan is not related to the sensory aspect of the vision or the philosophical interpretation of atrivial human experience. In this regard, a fundamental difference between Hindus, Buddhist, Jain and Christian art in relation to Muslim art is the non-existence of Sacred images in Islamic Temples, because Muslims claim that one should only worship God, and $\mathrm{He}$ has no physical image. Thus, the Muslim Temples are devoid of sacred images [34].

Second, the concept of Darshan is the core of the creation of the Hindu Temples and Hindu Sacred images that is common to various Western and Eastern religious traditions, namely Christian, Jewish, Muslim(Western religions) and Buddhist, Jain (Eastern religions). In fact, the Hindus claim that pilgrimage is the natural desire for Darshan of a certain Divine image, which is at the core in the construction of all Sacred Temples through ages, particularly in Western contemporary society [35], [36]. The deity is present in the Sacred image and the Temple is the place of epiphany of the Divine that leads to a change of consciousness mind and behaviour of the pilgrim[37]. For example, in the Western culture, we have the Sanctuary dedicated to the Immaculate Conception in southern France (Lourdes) [38], while in the Eastern culture, we have the Shrine in the Amarnath Cave dedicated to Shiva in northern India (Jammu and Kashmir) [39]. Thus, it is the pilgrim (or observer according to Quantum Mechanics) who chooses which Darshan he/she wants to experience in his/her life [40]. In this regard, devotion to the male Sacred Heart of Jesus image - present in various Shrines of Christian Temples -was the resulted of the "visions" that Saint Margaret Mary Alacoque[41] had during her life in order to bestow, Love, Light and Grace to human beings[42].Equally, the devotion to the female goddess Durga ("invincible") image - present in various shrines of Hindu Temples - was originated from a Hindu text called by Devi Mahatmya (part of the MarkandeyaPurana [43]), where the Holy Trinity of Men (Brahma (Father), Vishnu (Son), Shiva (Holy Spirit)) descends to the Ganges river and asks the goddess Durga to protect and take care of the Earth [44].

In fact, an important aspect in the process of construction of the Indian Temples involves the union of the male principle of creation -represented by the lingam(identical to the male sexual organ) - and the female aspect of creation - represented by the yoni(identical to the female sexual organ) - that leads to the union of the lingam-yoni described by Tantra philosophy [45].

For example, lingam is presented in some Indian Temples dedicated to Shiva (such as the Kailasa Temple of Ellora Caves, in Maharashtra), while yoni is presented in some Hindu Shrines dedicated to Shakti (such as the Shrine of Cát Tien, in Lam Dong). This process of inner union and balance, between the masculine and feminine side of each human being, has been extensively studied by Western psychology - the "Jungian" archetypes called by "animus" and "anima" [46] -which is the ultimate goal of Darshan: an "inner" marriage with their deity[47] which is experienced by the devotional life of priests and nuns of the various religious traditions.

Nowadays, some pilgrims have already experienced the Darshan of Indian Holy women, known as "Mother" [48], [49], in Sacred Temples of southern India.Some devotees have spoken about joy and fulfillment in all areas of their life, after the experience of Darshan[50].

\section{REFERENCES}

[1] Brown, Percy. Indian Architecture.Vol.1:Buddhist and Hindu Period; Vol.2:Islamic Period. Bombay.1959.

[2] Craven, Roy. A concise History of Indian Art. Oxford University Press. 1975.

[3] Mitter, Partha. Indian Art (Oxford History of Art).Oxford University Press. 2001.

[4] Anonymous. Bhagavad-Guita.Organized by AntónioBarahona.Assírio\&Alvim. 2007.

[5] Nicolescu, Basarab. The Hidden Third.Quantum Prose. 2016.

[6] Williams, Bryan. Extrasensory Perception and Brain Hemisphere, Neuro Quantology, 10(3):350-373. 2012.

[7] Huntington, Susan. The Art of Ancient India. New York. 1984.

[8] Kenoyer, Jonathan. Ancient Cities of the Indus Valley Civilization.Oxford University Press. 1998.

[9] Goswamy, Brijen. Essence of Indian Art.Asian Art Museum of San Francisco.1986. 
[10] Dehejia, Vidya. Indian Art.Phaidon Press.1997.

[11] Ketkar, Anil. The History of Indian Art.Jyotsna Prakashan. 2017.

[12] Dallapiccola, Anna. The Stupa: Its Religious, Historical and Architectural Significance. Wiesbaden. 1980.

[13] Knox, Robert. Amaravati: Buddhist Sculpture from the Great Stupa. London. 1992.

[14] Williams, Joanna. The Art of Gupta India: Empire and Province. Princeton. 1982.

[15] Behl, Benoy. The Ajanta Caves. London. 1998.

[16] Collins, Charles. The Iconography and Ritual of Siva at Elephanta. Albany. 1988.

[17] Starza, O. The Jagannatha Temple at Puri.Its Architecture, Art and Cult. E.J. Brill.1993.

[18] Berkson, Carmel. Ellora: Concept and Styles. New Delhi.1992.

[19] Acharya, Prasanna. An encyclopedia of Hindu architecture.Oxford University Press. 2010.

[20] Hardy, Adam. The Temple Architecture of India.Wiley. 2007.

[21] Stein, Burton. South Indian Temples.Vikas. 1978.

[22] Michell, George. Hindu Art and Architecture.Thames\&Hudson. 2000.

[23] Kramrisch, Stella. The Hindu Temple.Vol.1 and Vol.2.Princeton University Press. 1946.

[24] Grabar, Oleg. The Formation of Islamic Art. New Haven. 1973.

[25] Stein, Burton. Vijayanagara. Cambridge. 1999.

[26] Begley, Wayne. The Myth of the Taj Mahal and a New Theory of its Symbolic Meaning, TheArt Bulletin, 61(1): 7-37. 1979.

[27] Tillotson, Giles. The Rajput Palaces: The Development of an Architectural Style:1450-1750. New Haven and London. 1987.

[28] Pearson, M. The Portuguese in India.Cambridge.1987.

[29] Pal, Pratapaditya and Dehejia, Vidya. From Merchants to Emperors: British Artists and India: 1757-1930. Ithaca. 1986.

[30] Kapur, Geeta. Contemporary Indian Artists. New Delhi. 2000.

[31] Trautmann, Thomas. India: Brief History of a Civilization. Oxford University Press. 2015.

[32] Chakrabarti, Arindam. The Bloomsbury Research Handbook of Indian Aesthetics and the Philosophy of Art.Bloomsbury Academic. 2018.

[33] Dasgupta, Surendranath. A History of Indian Philosophy.MotilalBanarsidass. 5 Vols. 1997.

[34] Madigan, Daniel. The Quran’s Self-Image.Princeton University Press. 2001.

[35] Bettwy, Sr. Isabel. I Am the Guardian of the Faith: Reported Apparitions of the Mother of God in Ecuador. Franciscan University Press. 1991.

[36] Weible, Wayne. Medjugorje: The Message. Paraclete Press. 1989.

[37] Oviedo, Lluis and Coucier, Scarlett and Farias, Miguel. Rise of Pilgrims on the Camino to Santiago: Sign of Change or Religious Revival? In "The Pilgrimage Project:A study of motivations and experiences in Sacred Space”. Religious Studies Review, 56(3): 433-442. 2014.

[38] Editors, Charles. The Sanctuary of Our Lady of Lourdes: The History and Legacy of the Catholic church's Haven of Miracles. Charles River Editors. 2018.

[39] Coomaraswamy, Ananda. The Dance of Shiva: Essays on Indian Art and Culture. Dover Publications. 2011.

[40] Eck, Diana. Darshan: Seeing the Divine Image in India. Chambersburg, PA. 1981.

[41] Alacoque, S. Margarida. Autobiografia de Santa Margarida-Maria Alacoque. Editorial A.O. 2008.

[42] Bainvel, Jean. Devotion to the Sacred Heart of Jesus, The Catholic Encyclopedia, Vol. 7, New York: Robert Appleton Company. 1910.

[43] Coburn, Thomas. Devi Mahatmya, The Crystallization of the Goddess Tradition. South Asia book.2002.

[44] Kinsley, David. Hindu Goddesses: Vision of the Divine Feminine in the Hindu Religious Traditions.University of California Press. 1988.

[45] Wallis, Christopher. Tantra Illuminated: The Philosophy, History and Practice of a Timeless Tradition. Mattamayura Press. 2013.

[46] Jung, Carl. On the Nature of the Psyche.London: Ark Paperbacks. 1947.

[47] Harman, William. The Sacred marriage of a Hindu goddess.MotilalBanarsidass. 1992.

[48] Olati, Adilaksmi. The Mother. Mother Meera Distributors. 1995.

[49] Bess, Savitri. The Path of Mother: With the Divine Guidance of the Holy MotherAmmachi. Wellspring / Ballantine. 2000. 
[50] Meera, Mother. Moments with Mother: Devotees'Experiences with Mother Meera on Her North America Tour. Adilakshmi GmbH. 2015.

\section{AUTHOR'S BIOGRAPHY}

Paulo Nuno Martins, is a Chemical Engineer from Instituto Superior Técnico, University of Lisbon and a PhD in History and Philosophy of Science from Faculty of Sciences and Technology, New University of Lisbon. The author has studied for four years Oriental languages and culture (Indian, Chinese, Japanese, Arabic) and he is currently a researcher in History of Science at Interuniversity Center for History of Science and Technology, New University of Lisbon, Portugal (CIUHCT-UNL).

Citation: Paulo Nuno Martins, "A Concise History of Indian Sacred Art: Some Philosophical Considerations". International Journal of History and Cultural Studies (IJHCS). vol 4, no. 3, 2018, pp. 19-25. doi: DOI: http://dx.doi.org/ 10.20431/2454-7654.0403004.

Copyright: (C) 2018 Authors. This is an open-access article distributed under the terms of the Creative Commons Attribution License, which permits unrestricted use, distribution, and reproduction in any medium, provided the original author and source are credited. 